\title{
PERCEPATAN EKONOMI PEDESAAN MELALUI PEMBANGUNAN PERKEBUNAN KELAPA SAWIT *
}

\author{
Almasdi Syahza \\ Lembaga Penelitian Universitas Riau \\ Kampus Binawidya km 12,5 Pekanbaru 28293 Indonesia
}

Diterima 9 Oktober 2011 / Disetujui 2 Nopember 2011

\begin{abstract}
This research assessed the impact of oil palm plantation development to the acceleration of economic development of community in effort to alleviate poverty in rural areas. The research was conducted through survei with descriptive method. Information obtained through the approach of Rapid Rural Appraisal (RRA). The results obtained by oil palm plantation activities in the rural areas created a figure amounting to 3.03 of multiplier effect, especially in employment and business opportunity. In year 2003, the farmer's welfare index of rural areas amounting to 1.72. It means the growth of the farmer's welfare increased by 172 percent. In the period of 2003-2006, farmers' welfare index was 0.18 and the period of 20062009 also experienced positive at 0.12. It means the welfare of farmers during this period increased by 12 percent.
\end{abstract}

Keywords: multiplier effect, rural areas economic, cluster, oil palm plantation

\begin{abstract}
Abstrak: Kegiatan penelitian untuk mengkaji dampak pembangunan perkebunan kelapa sawit terhadap percepatan pembangunan ekonomi masyarakat dalam upaya mengetaskan kemiskinan di daerah pedesaan. Penelitian dilakukan melalui survei dengan metode deskriptif (Descriptive Research). Informasi diperoleh melalui pendekatan Rapid Rural Appraisal (RRA). Hasil diperoleh kegiatan perkebunan kelapa sawit di pedesaan menciptakan angka multiplier effect sebesar 3,03, terutama dalam lapangan pekerjaan dan peluang berusaha. Indek kesejahteraan petani di pedesaan tahun 2003 sebesar 1,72. Berarti pertumbuhan kesejahteraan petani mengalami kemajuan sebesar 172 persen. Pada periode tahun 2003-2006 indek kesejahteraan petani 0,18 dan periode tahun 2006-2009 juga mengalami positif sebesar 0,12. Ini berarti kesejahteraan petani pada periode tersebut meningkat sebesar 12 persen.
\end{abstract}

Kata kunci: multiplier efek, ekonomi pedesaan, cluster, perkebunan kelapa sawit

\section{PENDAHULUAN}

Pertumbuhan ekonomi Riau selama periode tahun 2005-2010 sebesar 14,35 persen, pertumbuhan yang tinggi ini ditopang oleh sektor pertanian khususnya subsektor perkebunan. Pada tahun 1996 sektor pertanian sebagai tulang punggung ekonomi rakyat pedesaan Riau hanya mengalami pertumbuhan sebesar 2 persen sementara sektor industri melaju sebesar 14

\footnotetext{
* Hasil penelitian Hibah Kompetensi Tahun I dan II, Tahun 2009-2010, DP2M Dikti Jakarta
}

persen. Namun pada tahun 2002 sektor pertanian sudah mulai membaik dengan angka pertumbuhan sebesar 6,06 persen, sedangkan sektor industri 12,47 persen. Selama periode 20052010 perumbuhan sektor pertanian atas dasar harga konstan 4,08 persen, sedangkan atas dasar harga berlaku sebesar 19,07 persen. Tingginya pertumbuhan sektor pertanian karena ditunjang oleh tanaman perkebunan yang berorientasi ekspor seperti kelapa sawit, karet, gambir, dan sebagainya.

Pemerintah Daerah Riau mencanangkan pembangunan Daerah Riau melalui program 
pemberantasan kemiskinan, kebodohan dan pembangunan infrastruktur (lebih dikenal dengan program K2I). Setiap pembangunan yang dilaksanakan di Daerah Riau harus mengacu kepada Program K2I. Karena pembangunan daerah sangat ditentukan oleh potensi yang dimiliki oleh suatu daerah, maka kebijaksanaan yang dibuat oleh pemerintah daerah harus mengacu kepada potensi daerah yang berpeluang untuk dikembangkan, khususnya sektor perkebunan (kelapa sawit, karet, dan kelapa. Sampai saat ini kelapa sawit merupakan tanaman primadona masyarakat Riau.

Ada beberapa alasan kenapa Pemerintah Daerah Riau mengutamakan kelapa sawit sebagai komoditas utama, antara lain: Pertama, dari segi fisik dan lingkungan keadaan daerah Riau memungkinkan bagi pengembangan perkebunan kelapa sawit. Kondisi daerah Riau yang relatif datar memudahkan dalam pengelolaan dan dapat menekan biaya produksi; Kedua, kondisi tanah yang memungkinkan untuk ditanami kelapa sawit menghasilkan produksi lebih tinggi dibandingkan daerah lain; Ketiga, dari segi pemasaran hasil produksi Daerah Riau mempunyai keuntungan, karena letaknya yang strategis dengan pasar internasional yaitu Singapura; Keempat, Daerah Riau merupakan daerah pengembangan Indonesia Bagian Barat dengan dibukanya kerjasama Indonesia Malaysia Singapore Growth Triangle (IMS-GT) dan Indonesia Malaysia Thailand Growth Triangle (IMT-GT), berarti terbuka peluang pasar yang lebih menguntungkan; dan kelima, berdasarkan hasil yang telah dicapai menunjukkan bahwa kelapa sawit memberikan pendapatan yang lebih tinggi kepada petani dibandingkan dengan jenis tanaman perkebunan lainnya (Syahza, 2002).

Kelapa sawit merupakan pengembangan subsektor perkebunan yang berbasis agribisnis. Aktivitas perkebunan kelapa sawit dan produk turunannya memberikan nilai tambah yang tinggi di sektor perokonomian. Menurut Gumbira-Sa'id, E. dan L. Febriyanti (2005), sektor agribisnis merupakan lapangan kerja yang berperan besar dalam penurunan tingkat pengangguran. Karena itu pengembangan pertanian sudah seharusnya dipusatkan kepada pengembangan produktivitas yang dicapai melalui ma- najemen agribisnis yang ditata dengan baik Agribisnis mencakup keseluruhan perusahaan yang terkait dengan kegiatan usahatani dan pemasarannya sehingga produksinya sampai pada konsumen akhir. Agribisnis meliputi seluruh sektor bahan masukan usahatani, terlibat dalam proses produksi, dan pada akhirnya menangani pemprosesan, penyebaran, penjualan secara borongan dan eceran produk kepada konsumen akhir. Agribisnis merupakan sektor perekonomian yang menghasilkan dan mendistribusikan masukan bagi pengusahatani, memasarkan, dan memproses serta mendistribusikan produk usahatani kepada pemakai akhir.

Di masa lalu, petani di pedesaan berada pada mata rantai yang memberikan nilai tambah kecil (pertanian primer) dalam keseluruhan kegiatan ekonomi yang berbasis pertanian, mulai dari industri hulu hingga hilir, sehingga wajar jika pendapatan petani rendah. Sementara mereka yang menguasai mata rantai kegiatan ekonomi yang memberikan nilai tambah besar seperti industri hulu dan hilir pertanian beserta kegiatan perdagangannya, mampu berkembang dan menjadi konglomerat besar. Oleh sebab itu kita perlu memperkuat ekonomi rakyat agar mampu merebut nilai tambah yang besar. Menurut Saragih (2001a) dalam upaya penguatan ekonomi rakyat, industrialisasi pertanian merupakan syarat keharusan (necessary condition). Industrialisasi menjamin iklim makro kondusif bagi pengembangan ekonomi rakyat yang sebagian besar berada pada kegiatan ekonomi berbasis pertanian. Untuk penguatan ekonomi rakyat secara riil, diperlukan syarat kecukupan (sufficient condition) berupa pengembangan organisasi bisnis petani yang dapat merebut nilai tambah yang tercipta pada setiap mata rantai ekonomi dalam industrialisasi pertanian.

Hasil penelitian Syahza (2007), kegiatan agribisnis melalui pembangunan perkebunan kelapa sawit di daerah Riau membawa perubahan besar terhadap keadaan masyarakat pedesaan. Di samping itu dengan berkembangnya perkebunan kelapa sawit juga merangsang tumbuhnya industri pengolahan yang bahan bakunya dari kelapa sawit. Pembangunan perkebunan kelapa sawit mempunyai dampak ganda terhadap ekonomi wilayah, terutama 
sekali dalam menciptakan kesempatan dan peluang kerja. Pembangunan perkebunan kelapa sawit ini telah memberikan tetesan manfaat (trickle down effect), sehingga dapat memperluas daya penyebaran (power of dispersion) pada masyarakat sekitarnya. Semakin berkembangnya perkebunan kelapa sawit, semakin terasa dampaknya terhadap tenaga kerja yang bekerja pada sektor perkebunan dan sektor turunannya. Dampak tersebut dapat dilihat dari peningkatan pendapatan masyarakat petani, sehingga meningkatnya daya beli masyarakat pedesaan, baik untuk kebutuhan primer maupun kebutuhan sekunder.

Berdasarkan peran kelapa sawit terhadap perekonomian pedesaan dan perkembangan luas areal perkebunan kelapa sawit di daerah Riau, maka penelitian ini mencoba mengidentifikasi dampak pembangunan perkebunan kelapa sawit terhadap percepatan pembangunan ekonomi masyarakat di pedesaan dalam upaya mengentaskan kemiskinan melalui peningkatan pendapatan masyarakat petani. Untuk itu rumusan masalah yang diteliti adalah: 1) Apakah kegiatan kelapa sawit dapat menciptakan multiplier effect ekonomi yang besar di daerah pedesaan? 2) Apakah pembangunan perkebunan kelapa sawit di daerah Riau dapat meningkatkan kesejahteraan masyarakat pedesaan?

Setelah penelitian ini dilakukan dapat memberikan gambaran perkembangan pembangunan perkebunan kelapa sawit dan dampaknya terhadap perkembangan ekonomi masyarakat pedesaan khususnya upaya mengentaskan kemiskinan bagi masyarakat petani di pedesaan.

\section{METODE PENELITIAN}

Penelitian ini dilakukan melalui survei dengan metode deskriptif (Descriptive Research). Tujuan penelitian deskriptif adalah untuk membuat penyanderaan secara sistematis, faktual dan akurat mengenai fakta-fakta dan sifat-sifat populasi (petani kelapa sawit) pada daerah terpilih sebagai lokasi penelitian.

Lokasi penelitian dilakukan pada lima kabupaten di Provinsi Riau, yaitu: Kabupaten Rokan Hulu, Rokan Hilir, Indragiri Hulu, Ku- antan Singingi, dan Kabupaten Bengkalis. Alasan pemilihan lima kabupaten tersebut, antara lain: 1) dalam rencana tata ruang wilayah (RTRW) provinsi Riau, daerah tersebut merupakan bahagian dari pusat pengembangan perkebunan khususnya kelapa sawit (Dinas Perkebunan Provinsi Riau, 2004); 2) umur kelapa sawit di daerah terpilih pada usia produksi optimum yaitu umur 10 sampai 20 tahun (baik produksi TBS, minyak sawit, dan inti sawit); 3 ) pada daerah terpilih dikembangkan perkebunan plasma kelapa sawit dengan perusahaan BUMN dan perusahaan swasta sebagai inti; 4) di sekitar pengembangan perkebunan kelapa sawit tersebut banyak masyarakat setempat melakukan usahatani kelapa sawit secara swadaya; dan 5) dari daerah yang terpilih sebagai sampel mempunyai produktivitas kebun yang berbeda.

$$
n=\frac{\frac{Z^{2} \cdot P \cdot Q}{d^{2}}}{1+\frac{1}{N}\left[\frac{Z^{2} \cdot P \cdot Q}{d^{2}}-1\right]}
$$

Sampel diambil dari masyarakat di daerah penelitian yang terpilih. Rumus untuk ukuran sampel adalah (Syahza, 2009):

Keterangan: $\mathrm{n}$ adalah ukuran sampel; $\mathrm{P}$ merupakan proporsi dari masing-masing kelompok sampel (petani plasma dan petani swadaya) pada kelas yang terpilih; sedangkan $\mathrm{Q}=1-\mathrm{P}$. $\mathrm{N}$ adalah ukuran populasi; $Z$ adalah nilai deviasi normal terhadap probabilitas keyakinan yang diinginkan, dan d adalah tingkat kesalahan yang diinginkan. Penelitian ini menggunakan batas probabilitas keyakinan sebesar 95 persen.

Pengambilan sampel dilakukan secara Stratified Cluster Sampling sehingga masing-masing daerah terpilih terdapat sampel yang mewakili. Metode ini digunakan dengan pertimbangan bahwa letak lokasi penelitian yang berpencaran, karakteristik masyarakat sebagai objek penelitian yang beragam. Pada masing-masing cluster yang terpilih, diambil dua macam responden, yaitu responden dari petani perkebunan dan responden dari petani nonperkebunan.

Dari masing-masing daerah terpilih sebagai sampel, ditentukan proporsi $(\mathrm{P})$ dari masing-masing kelompok sampel yaitu petani per- 
Tabel 1. Jumlah Petani Perkebunan Kelapa Sawit pada Daerah Sampel Tahun 2010

\begin{tabular}{lcrcc}
\hline & \multirow{2}{*}{ Kabupaten } & \multicolumn{3}{c}{ Petani Kelapa Sawit } \\
\cline { 3 - 5 } & & Plasma & Swadaya & Jumlah \\
\hline 1. Rokan Hulu & 9.335 & 13.050 & 22.385 \\
2. Rokan Hilir & 14.579 & - & 14.579 \\
3. Indragiri Hulu & 8.769 & 1.394 & 10.163 \\
4. Kuantan Singingi & 24.659 & 7.819 & 32.478 \\
5. Bengkalis & & 39.769 & 17.852 & 57.621 \\
\multicolumn{1}{c}{ Jumlah } & Petani & 97.111 & 40.115 & 137.226 \\
& Persentase & 70,77 & 29,23 & 100,00 \\
\hline
\end{tabular}

Sumber: Dinas Perkebunan Provinsi Riau, 2009

kebunan dan nonperkebunan. Hasil perhitungan tersebut disajikan pada Tabel 1.

Tingkat keyakinan pada penelitian ini adalah 95\% $(\alpha=5 \%)$, dan diasumsikan datanya berdistribusi normal, sehingga diperoleh nilai $\mathrm{z}$ sebesar 1,96. Dengan menggunakan rumus Cochran, maka diperoleh ukuran sampelnya sebesar 317 responden. Untuk lebih jelasnya ukuran sampel pada masing-masing daerah dan kelompok disajikan pada Tabel 2.

Pengumpulan data primer dilakukan dengan menggunakan daftar pertanyaan yang telah disusun berdasarkan kebutuhan penelitian. Kuesioner berperan sebagai pedoman umum untuk mengingatkan peneliti agar tidak menyimpang dari tujuan penelitian. Untuk mendapatkan informasi yang akurat dilakukan dengan metode Rapid Rural Appraisal (RRA), yaitu suatu pendekatan partisipatif untuk mendapatkan data/informasi dan penilaian (assesment) secara umum di lapangan dalam waktu yang relatif pendek. Kelebihan pendekatan ini adalah penelitian bisa mencakup daerah yang lebih luas dalam waktu relatif singkat untuk mendapatkan informasi yang luas secara umum.
Dalam metode RRA ini informasi yang dikumpulkan terbatas pada informasi dan yang dibutuhkan sesuai dengan tujuan penelitian, namun dilakukan dengan lebih mendalam dengan menelusuri sumber informasi sehingga didapatkan informasi yang lengkap tentang sesuatu hal.

Untuk mengurangi penyimpangan (bias) yang disebabkan oleh unsur subjektif peneliti maka setiap kali selesai melakukan interview dengan responden dilakukan analisis pendahuluan. Kalau ditemui kekeliruan data dari yang diharapkan karena disebabkan adanya informasi yang keliru atau salah interpretasi maka dilakukan konfirmasi terhadap sumber informasi atau dicari informasi tambahan sehingga didapatkan informasi yang lebih lengkap.

Pendekatan angka multiplier effect ekonomi pada kegiatan perkebunan kelapa sawit digunakan formula sebagai berikut (Tiebout dalam Tulus T.H. Tambunan, 2001):

$$
K=\frac{1}{1-(\text { MPC } \times \text { PSY })}
$$

\begin{tabular}{|c|c|c|c|c|c|c|}
\hline \multirow{2}{*}{$\mathbf{P}$} & \multirow{2}{*}{ Q } & \multirow{2}{*}{ D } & \multirow{2}{*}{$\mathbf{Z}$} & \multirow{2}{*}{$\mathbf{N}$} & \multicolumn{2}{|c|}{ Ukuran Sampel } \\
\hline & & & & & Plasma & Swadaya \\
\hline 0,71 & 0,29 & $5 \%$ & 1,96 & 317 & 224 & 93 \\
\hline \multicolumn{4}{|c|}{ 1. Rokan Hulu } & 52 & 22 & 30 \\
\hline \multicolumn{4}{|c|}{ 2. Rokan Hilir } & 34 & 34 & - \\
\hline \multicolumn{4}{|c|}{ 3. Indragiri Hulu } & 23 & 20 & 3 \\
\hline \multicolumn{4}{|c|}{ 4. Kuantan Singingi } & 75 & 57 & 18 \\
\hline \multicolumn{4}{|c|}{ 5. Bengkalis } & 133 & 92 & 41 \\
\hline
\end{tabular}

Tabel 2. Ukuran Sampel pada Masing-masing Daerah Terpilih 
Keterangan: $\mathrm{K}$ adalah pengaruh ekonomi wilayah (multiplier effect); MPC adalah proporsi pendapatan petani yang dibelanjakan di daerah tersebut; dan PSY adalah bagian dari pengeluaran petani yang menghasilkan pendapatan di daerah tersebut. Semakin tinggi angka multiplier effect kegiatan perkebunan kelapa sawit (K) maka semakin tinggi pula perputaran uang di daerah pedesaan.

Untuk mengetahui tingkat kemakmuran dan tingkat kesejahteraan masyarakat pedesaan terutama di sekitar pengembangan perkebunan kelapa sawit dilakukan pengujian dengan rumus sebagai berikut (Todaro, Michael P, 2006):

$$
\mathrm{G}=\mathrm{w}_{1} \mathrm{~g}_{1}+\mathrm{w}_{2} \mathrm{~g}_{2}+\ldots \ldots+\mathrm{w}_{\mathrm{i}} \mathrm{g}_{\mathrm{i}}
$$

$G$ adalah indek pertumbuhan kesejahteraan sosial; $g_{i}$ adalah tingkat pertumbuhan sosial quantile ke $\mathrm{i}$; dan $w_{i}$ merupakan bobot kesejahteraan kelompok quantile ke i.

Peningkatan kesejahteraan masyarakat pedesaan sebagai akibat dari pembangunan perkebunan kelapa sawit di Daerah Riau ditunjukkan dengan semakin besarnya nilai indek pertumbuhan kesejahteraan $(G)$ dari periode ke periode.

\section{HASIL DAN PEMBAHASAN}

\section{Profil Petani Kelapa Sawit di Riau}

Perkembangan teknologi produksi dan pertumbuhan tingkat pendapatan telah menyebabkan terjadinya perubahan struktur ekonomi Riau selama dua dasawarsa terakhir ini. Kebutuhan tenaga kerja mengalami pergeseran dari tenaga kerja tidak terampil ke tenaga kerja terampil. Hal yang sama juga akan terjadi pada sektor pertanian. Kebutuhan tenaga kerja pertanian yang terampil mengalami peningkatan sejalan dengan berubahnya orientasi sektor pertanian dari subsisten ke arah komersial. Kebutuhan tenaga kerja terampil dan berilmu semakin diperlukan di era perdagangan bebas. Untuk mampu bersaing produk pertanian dengan negara lain diperlukan petani atau tenaga kerja yang tidak hanya menguasai ilmu pengetahuan dan tekno- logi yang tangguh tetapi juga mampu mengatasi berbagai masalah dalam pekerjaan dan memenangkan persaingan pasar global.

Dari hasil lapangan ditinjau dari aspek pendidikan sampel, dapat diungkapkan bahwa kualitas sumberdaya petani masih rendah. Berikut ini disajikan pada Tabel 3 tentang lama pendidikan yang ditempuh oleh petani.

Rataan lama pendidikan sampel 8,77 tahun atau sebagian sampel berpendidikan sederajat SLTP. Tingkat pendidikan petani akan berakibat lambatnya penerapan perubahan teknologi. Hasil temuan di lapangan ditemukan ada 13 orang (4,1 persen) sampel yang berpendidikan sarjana. Hal ini disebabkan sebagian dari petani merupakan pegawai negeri sipil atau pekerja di perusahaan perkebunan. Sampel tersebut pekerjaan usahatani kelapa sawit merupakan pekerjaan sampingan. Pada umumnya keterampilan lebih mudah ditingkatkan apabila pendidikan semakin tinggi. Pentingnya pendidikan tersebut bagi petani supaya dapat dengan mudah meningkatkan keterampilannya dan mengarah kepada keahlian, sehingga nanti akan dapat meningkatkan produktivitas baik petani maupun lahan mereka.

Dari sisi lain sampel yang berpendidikan rendah sebesar 25,55 persen (tidak sekolah dan tamat SD) pada umumnya petani plasma, sedangkan sampel yang berpendidikan lebih lanjut pada umumnya penduduk tempatan (petani swadaya). Dari pengamatan di lapangan terlihat tumbuhnya daerah di sekitar kawasan perkebunan disebabkan banyaknya pendatang, sementara masyarakat tempatan tidak banyak terlibat dalam kegiatan perkebunan.

Kalau diperhatikan pendidikan anak dari sampel pada umumnya anak mereka masih dalam sekolah. Ada 18,93 persen anak mereka yang menempuh pendidikan tinggi. Dari hasil pengamatan di lapangan pendidikan anak dibandingkan pendidikan orang tua jauh lebih tinggi. Berdasarkan hasil wawancara dengan sampel pada umumnya mereka menginginkan anaknya berpendidikan supaya kelak kehidupan anaknya jauh lebih baik dari orang tua. Begitu juga dalam kegiatan pertanian, anak-anak mereka tidak banyak membantu karena sedang di bangku pendidikan. Kegiatan usahatani kela- 
Tabel 3. Tingkat Pendidikan Tertinggi Sampel

\begin{tabular}{crrrrr}
\hline \multirow{2}{*}{ No } & \multirow{2}{*}{ Tingkat Pendidikan } & \multicolumn{3}{c}{ Pendidikan Tertinggi Sampel } \\
\cline { 3 - 6 } & & \multicolumn{2}{c}{ Orang Tua } & \multicolumn{3}{c}{ Anak $^{*}$} \\
\cline { 3 - 6 } & & Frekuensi & 2,52 & 0 & 0,00 \\
\hline 1. & Tidak Sekolah & 73 & 23,03 & 0 & 0,00 \\
2. & Sekolah Dasar & 152 & 47,95 & 121 & 38,17 \\
3. & Sekolah Lanjutan Pertama & 71 & 22,40 & 136 & 42,90 \\
4. & Sekolah Lanjutan Atas & 13 & 4,10 & 60 & 18,93 \\
5. & Perguruan Tinggi & 317 & 100,00 & 317 & 100,00 \\
\hline
\end{tabular}

Rata-rata lamanya pendidikan orang tua 8,77 tahun (SLTP)

Rata-rata lamanya pendidikan anak 11,8 tahun (SLTA)

* Pendidikan anak petani tertinggi pada waktu survei

Sumber: Syahza, 2010

pa sawit pada umumnya mereka mengupahkan kepada tenaga kerja setempat.

Dari uraian di atas dapat diungkapkan bahwa pengembangan kawasan perkebunan telah memberikan dampak positif terhadap pendidikan masyarakat, baik masyarakat yang terlibat langsung maupun masyarakat sekitarnya. Dampak ini dapat diperlihatkan dengan berdirinya sekolah yang dapat dimanfaatkan oleh anak-anak dari masyarakat yang terlibat langsung dengan kegiatan perkebunan maupun masyarakat sekitarnya.

Dari segi umur, sampel yang diamati tergolong usia produktif atau relatif muda dengan rataan umur 43,7 tahun, seperti yang disajikan pada Tabel 4 .

Sampel yang berusia diatas 58 tahun hanya sebanyak 3,79 persen. Relatif mudanya umur sampel petani kelapa sawit akan dapat mening- katkan produktivitas mereka. Namun dari hasil pengamatan di lapangan memperlihatkan kegiatan usahatani kelapa sawit lebih banyak dengan sistem upah, mulai dari penyiangan, pemupukan, dan panen. Waktu mereka lebih banyak terpakai untuk bersenang-senang bersama keluarga dan teman-teman mereka.

Berdasarkan kelompok pendapatan antara petani plasma dan swadaya memperlihatkan masih rendahnya pendapatan petani swadaya. Pendapatan petani plasma pada umumnya di atas Rp3.901.709 per bulan, sedangkan petani swadaya sebesar Rp2.996.672 per bulan. Jika ditinjau dari segi pendapatan kelapa sawit dan pendapatan lainnya, maka 62,95 persen petani plasma berpenghasilan:Rp2.289.809 sampai dengan Rp4.013.114, sedangkan petani swadaya sebanyak 67,72 persen. Begitu juga bagi yang berpenghasilan di atas empat juta rupiah, peta-

Tabel 4. Kelompok Umur Sampel

\begin{tabular}{cccr}
\hline No & Kelompok Umur & Frekuensi & Persentase \\
\hline 1 & $29-33$ & 16 & 5,05 \\
2 & $34-38$ & 78 & 24,61 \\
3 & $39-43$ & 92 & 29,02 \\
4 & $44-48$ & 78 & 24,61 \\
5 & $49-53$ & 23 & 7,26 \\
6 & $54-58$ & 18 & 5,68 \\
7 & $>58$ & 12 & 3,79 \\
& Jumlah & 317 & 100,00 \\
\hline
\end{tabular}

Rata-rata umur petani sampel 43,7 tahun

Sumber: Syahza, 2010 
ni plasma sebanyak 37,05 persen, dan petani swadaya hanya 32,26 persen.

Dari segi pendapatan rata-rata per bulan, untuk petani plasma sebesar Rp4.125.242 dan petani swadaya sebesar Rp3.475.029. Ada beberapa hal yang menyebabkan ini terjadi, antara lain: Pertama, produktivitas kebun petani plasma lebih tinggi dibandingkan dengan produktivitas lahan petani swadaya yaitu masing-masing 1,86 dan 1,25 ton per hektar; Kedua, perbedaan harga tandan buah segar (TBS) antara kebun plasma dengan kebun swadaya, walaupun pada umur yang sama; Ketiga, petani plasma dapat meningkatkan pendapatannya melalui usaha sampingan seperti, warung, berdagang, transportasi, jasa, sehingga kegiatan sampingan ini juga dapat meningkatkan pendapatan keluarga. Di lain pihak masyarakat yang jauh dari pusat pertumbuhan (petani swadaya) kurang memanfaatkan kesempatan ini; dan keempat, masih adanya budaya dalam masyarakat pedesaan (petani swadaya) menerima apa adanya, tidak ada inisiatif untuk mengembangkan usaha lain, produktivitas masih rendah, dan masih mengandalkan hasil yang diperoleh dari alam terutama kebun. Pada Tabel 5 disajikan gambaran pendapatan petani baik yang bersumber dari kebun kelapa sawit maupun dari tambahan pendapatan di luar hasil perkebunan kelapa sawit.

Menyangkut dengan pemilikan kebun, rataan petani sawit memiliki luas kebun 2,48 ha per kk. Apabila dilihat dari segi jenis kegiatan, petani plasma rata-rata memiliki kebun kelapa sawit seluas 4,14ha per KK, sedangkan petani swadaya memiliki kebun lebih luas yaitu rata- rata 2,18ha. Namum pemilikan ini sebagian besar dimiliki oleh mereka yang sudah punya modal, sementara golongan bawah tetap mempunyai lahan yang kecil dan tidak berkembang. Begitu juga menyangkut dengan pemilikan lahan perkarangan. Penguasaan dan pemilikan lahan pekarangan terkait dengan kondisi rumah yang dimiliki masyarakat. Kondisi rumah yang dimiliki suatu rumah tangga atau luas rumah per jiwa sangat erat kaitannya dengan kenyamanan dan kesehatan.

\section{Analisis Multiplier Effect}

Pengembangan perkebunan di pedesaan telah membuka peluang kerja bagi masyarakat yang mampu untuk menerima peluang tersebut. Dengan adanya perusahaan perkebunan, mata pencaharian masyarakat setempat tidak lagi terbatas pada sektor primer dalam memenuhi kebutuhan keluarganya, tetapi telah memperluas ruang gerak usahanya pada sektor tertier. Bermacam sumber pendapatan yang memberikan andil yaitu pedagang (dagang barang-barang harian, dagang karet, tiket angkutan dan penjual es), pegawai (guru, pemerintahan desa), industri rumah tangga (industri tahu, roti, dan percetakan genteng), buruh kasar, nelayan, pencari kayu di hutan dan tukang kayu.

Selain besaran jumlah pendapatan pada masing-masing rumah tangga petani kelapa sawit, hal yang perlu dicermati dalam mengamati dampak pelaksanaan investasi perkebunan adalah timbulnya usaha-usaha baru yang dikelola oleh masyarakat. Kegiatan usaha tersebut pada dasarnya merupakan upaya pemanfaatan peluang usaha yang tercipta sebagai akibat ada-

Tabel 5. Kelompok Pendapatan Petani Plasma dan Swadaya Per Bulan

\begin{tabular}{|c|c|c|c|c|c|}
\hline \multirow{2}{*}{ No } & \multirow{2}{*}{ Kelompok Pendapatan (Rp) } & \multicolumn{2}{|c|}{ Petani Plasma } & \multicolumn{2}{|c|}{ Petani Swadaya } \\
\hline & & Frekuensi & $\%$ & Frekuensi & $\%$ \\
\hline 1 & $2.289 .809-<4.013 .114$ & 141 & 62,95 & 63 & 67,74 \\
\hline 2 & 4.013.114 - <5.736.419 & 73 & 32,59 & 21 & 22,58 \\
\hline 3 & $5.736 .419-<7.459 .724$ & 5 & 2,23 & 4 & 4,30 \\
\hline 4 & $7.459 .724-<9.183 .029$ & 3 & 1,34 & 3 & 3,23 \\
\hline 5 & $9.183 .029-10.906 .334$ & 2 & 0,89 & 2 & 2,15 \\
\hline Jumlah & & 224 & 100,00 & 93 & 100,00 \\
\hline \multicolumn{2}{|c|}{ Rata-rata pendapatan sampel } & \multicolumn{2}{|c|}{ 4.125.242 } & \multicolumn{2}{|c|}{3.475 .029} \\
\hline
\end{tabular}

Sumber: Almasdi Syahza, 2010 
nya mobilitas penduduk, baik yang terpengaruh secara langsung maupun sebagai akibat usaha yang tercipta oleh adanya pengaruh tidak langsung dari pembangunan perkebunan yang memungkinkan terbukanya peluang usaha lainnya.

Suatu peluang usaha akan menjadi sumber pendapatan yang memberikan tambahan penghasilan kepada masyarakat jika mampu menangkap peluang usaha yang potensial dikembangkan menjadi suatu kegiatan usaha yang nyata. Dengan demikian kemampuan masyarakat memanfaatkan peluang yang ada akan dipengaruhi oleh kemampuan masyarakat dalam menangkap peluang itu sendiri. Yang kedua adalah kemampuan mengorganisir sumberdaya yang dimiliki sedemikian rupa sehingga peluang yang potensial menjadi usaha yang secara aktual dapat dioperasionalkan.

Walaupun tidak semua kegiatan perkebunan memberikan atau menyebabkan timbulnya sumber-sumber pendapatan bagi masyarakat, namun tergantung kepada jenis investasi perkebunan (inti atau plasma) dan sektor ekonomi yang akan dilakukan. Investasi tersebut pada akhirnya akan berpengaruh kepada sejauh mana manfaat kegiatan perkebunan memberi tetesan pada masyarakat sekitarnya. Kebijaksanaan pemerintah dan kemampuan masyarakat dalam memperoleh manfaat dari adanya pembangunan perkebunan sangat berpengaruh. Hal ini akan menentukan variasi sumber-sumber pendapatan yang muncul kemudian.

Secara umum dapat diungkapkan bahwa dengan adanya kawasan perkebunan telah menyebabkan munculnya sumber-sumber pendapatan baru yang bervariasi. Sebelum dibukanya kawasan perkebunan di pedesaan, sampel mengungkapkan sumber pendapatan masyarakat relatif homogen, yakni menggantungkan hidupnya pada sektor primer, memanfaatkan sumberdaya alam yang tersedia seperti apa adanya tanpa penggunaan teknologi yang berarti. Data lapangan mengungkapkan pada umumnya masyarakat hidup dari sektor pertanian sebagai petani tanaman pangan (terutama palawija) dan perkebunan (karet). Pada masyarakat di sekitar aliran sungai mata pencaharian sehari-hari pada umumnya sebagai nela- yan dan pencari kayu di hutan. Selain teknologi yang digunakan sangat sederhana dan monoton sifatnya tanpa pembaharuan (dari apa yang mampu dilakukan). Orientasi usahanya juga terbatas kepada pemenuhan kebutuhan keluarga untuk satu atau dua hari mendatang tanpa perencanaan pengembangan usaha yang jelas (subsisten).

Kondisi sebelum pembangunan perkebunan dengan setelah adanya kegiatan perkebunan pendapatan masyarakat semakin beragam. Keragaman ini semakin memperkuat stabilitas struktur pendapatan rumah tangga karena memberikan alternatif pemasukan bagi keluarga pada saat sumber pendapatan lain mengalami kegagalan usaha. Dari seluruh sampel yang diamati, rataan pendapatannya sebesar Rp3.404.123 per bulan, dan sekitar 7,76 persen bersumber dari pendapatan di luar perkebunan kelapa sawit.

Apabila ditinjau dari jenis kegiatan usahatani kelapa sawit terdapat terlihat perbedaan yang mencolok. Pendapatan rataan petani kelapa sawit plasma sebesar Rp3.638.101, sedangkan pendapatan petani kelapa sawit swadaya sebesar Rp2.688.819. Tingginya perbedaan ini lebih banyak disebabkan oleh beberapa hal, antara lain: 1) petani plasma lebih intensif dalam pengelolaan kebunnya dibandingkan petani swadaya; 2) kemampuan ekonomi petani plasma lebih baik sehingga mampu merawat kebun dan pembelian alsintan untuk keberhasilan usahatani kelapa sawit; 3) Terkait dengan harga, petani plasma lebih terjamin harga tandan buah kosong (TBS) karena dibeli oleh perusahaan inti melalui koperasi petani, sementara harga di tingkat petani swadaya lebih distorsi karena ditentukan oleh pihak toke di daerah pedesaan; 4) Lokasi perkebunan petani swadaya pada umumnya berpencar, dan hal tersebut menyebabkan pihak toke di tingkat desa punya alasan untuk menekan harga.

Kegiatan pembangunan perkebunan telah menimbulkan mobilitas penduduk yang tinggi. Akibatnya di daerah-daerah sekitar pembangunan perkebunan muncul pusat-pusat pertumbuhan ekonomi di pedesaan. Kondisi ini menyebabkan meningkatnya daya beli masyarakat pedesaan, terutama terhadap kebutuhan 
rutin rumah tangga dan kebutuhan sarana produksi perkebunan kelapa sawit. Dari sisi kebutuhan rumah tangga rata-rata pengeluaran petani setiap bulannya sebesar Rp2.573.654. Persentase masing jenis pengeluaran rutin petani kelapa sawit di pedesaan disajikan pada Tabel 6. Pengeluaran terbesar adalah kebutuhan hidup keluarga yakni untuk keperluan harian (dapur) sebesar 63,15 persen. tuk menyekolahkan anaknya ke jenjang pendidikan yang lebih tinggi.

Semua bentuk pengeluaran oleh petani apakah pengeluaran rutin atau pengeluaran untuk kebutuhan pemeliharaan kebun, pada umumnya dapat diperoleh di daerah, antara lain; pasar kecamatan, pasar desa, kedai-kedai, koperasi petani, atau pada pedagang keliling. Khusus untuk kebutuhan sarana produksi pada

Tabel 6. Rataan Jenis Pengeluaran Rutin Petani Kelapa Sawit Per Bulan

\begin{tabular}{|c|c|c|c|c|c|}
\hline \multirow{2}{*}{\multicolumn{2}{|c|}{ Jenis Pengeluaran }} & \multicolumn{2}{|c|}{ Plasma } & \multicolumn{2}{|c|}{ Swadaya } \\
\hline & & Nilai (Rp) & $\%$ & Nilai (Rp) & $\%$ \\
\hline 1 & Dapur (harian) & 1.651 .636 & 60,55 & 1.544 .714 & 73,48 \\
\hline 2 & Listrik & 109.671 & 4,02 & 66.257 & 3,15 \\
\hline 3 & Telepon & 75.748 & 2,78 & 38.571 & 1,83 \\
\hline 4 & Transportasi & 163.294 & 5,99 & 82.619 & 3,93 \\
\hline 5 & Kesehatan & 8.832 & 0,32 & 6.143 & 0,29 \\
\hline 6 & Rekreasi & 117.009 & 4,29 & 18.500 & 0,88 \\
\hline 7 & Pendidikan & 537.547 & 19,71 & 277,214 & 13,19 \\
\hline 8 & Asuransi kebun & 28.794 & 1,06 & 22.686 & 1,08 \\
\hline & Sosial & 35.336 & 1,30 & 45.500 & 2,16 \\
\hline \multicolumn{2}{|c|}{ Jumlah } & 2.727 .867 & 100 & 2.102 .204 & 100 \\
\hline \multicolumn{2}{|c|}{ Rataan pengeluaran } & \multicolumn{4}{|c|}{$\operatorname{Rp} 2.573 .654$} \\
\hline
\end{tabular}

Sumber: Syahza, 2010 
ganda tersebut diperoleh nilai MPC $=0,856$ dan nilai $P S Y=0,782$. Sehingga diperoleh angka pengganda sebesar 3,03. Nilai ini dapat memberikan arti bahwa setiap pembelanjaan oleh petani kelapa sawit di lokasi dan sekitarnya sebesar Rp100, secara sinerjik menjadikan perputaran uang di lokasi tersebut dan sekitarnya sebesar Rp303,00 melalui bentuk-bentuk usaha, baik sektor riil maupun jasa.

Nilai-nilai tersebut diperoleh dengan dasar dan asumsi sebagai berikut: (1) Persentase pendapatan petani sawit dibelanjakan di wilayah setempat (MPC) sekitar 85,64 persen. (2) Kebutuhan kegiatan perkebunan kelapa sawit yang dapat dipenuhi di wilayah setempat (PSY) sebesar 78, 26 persen, antara lain: (a) Kebutuhan peralatan pertanian ringan yang digunakan dalam kelola teknis diproyeksikan mampu dipenuhi oleh wilayah setempat. (b) Pengadaan sarana prasarana penunjang yang disediakan oleh perusahaan perkebunan, koperasi dapat dipenuhi oleh wilayah setempat.

Aktivitas pembangunan perkebunan kelapa sawit yang melibatkan banyak tenaga kerja dan investasi yang relatif besar untuk industri si, kecuali kota Pekanbaru. Jika dilihat dari segi dampak ekonominya menunjukkan hasil yang menggembirakan yakni terjadinya jumlah uang beredar di pedesaan. Hal ini berdampak terhadap meningkatnya daya beli masyarakat pedesaan, yang pada akhirnya meningkatnya mobilitas barang dan jasa (Syahza, 2003).

Ada dua kemungkinan sebab mengapa fenomena ini terjadi. Pertama, investasi sektor perkebunan dan produk turunannya di daerah menyebabkan disparitas spasial antar daerah semakin mengecil. Hal ini lebih disebabkan investasi sektor perkebunan lebih banyak menggunakan tenaga manual dibandingkan tenaga modern (peralatan), sehingga akan menambah pendapatan masyarakat di daerah sekitarnya; Kedua, kemungkinan pembangunan industri turunan kelapa sawit (PKS) di masingmasing daerah perkebunan juga menciptakan peluang kerja dan usaha bagi masyarakat tempatan, sehingga ini juga akan menambah daya beli masyarakat.

\section{Analisis Kesejahteraan Masyarakat Petani Kelapa Sawit}


Apabila diamati tingkat pertumbuhan indek kesejahteraan petani di Riau pada tahun 1995 sebesar 0,49 yang berarti tingkat pertumbuhan kesejahteraan meningkat sebesar 49 persen dari periode sebelumnya. Dari Tabel 7 terlihat pada tahun 1998 terjadi penurunan indeks kesejahteraan sebesar $-1,09$. Berarti kesejahteraan petani (khususnya masyarakat pedesaa) menurun dibandingkan pada tahun 1995. Penurunan ini disebabkan kondisi ekonomi nasional pada waktu itu tidak menguntungkan, harga barang melonjak naik, nilai tukar rupiah terhadap dollar Amerika menurun. Namun untuk tingkat golongan 80 persen berpendapatan rendah mengalami peningkatan. Yang paling besar adalah golongan 20 persen terendah. Ini disebabkan karena ketergantungan mereka terhadap produk luar (barang sektor modern sangat rendah). Mereka lebih banyak memakai barang sektor tradisional atau produksi lokal.

Setelah ekonomi pulih kembali pada tahun 2003 indeks pertumbuhan kesejahteraan petani di pedesaan meningkat lagi menjadi 1,72. Berarti pertumbuhan kesejahteraan petani mengalami kemajuan sebesar 172 persen. Pertumbuhan ini hanya dinikmati oleh kelompok yang berpenghasilan 40 persen tertinggi sebesar 32,8 persen, sedangkan kelompok 60 persen terendah justru mengalami penurunan kesejahteraan sebesar $-1,56$ persen. Namun pada tahun 2006 memperlihatkan indek pertumbuhan kesejahteraan petani sangat dirasakan oleh kelompok pendapatan 40 persen terendah (miskin), ini dibuktikan dengan angka indek pertumbuhan kesejahteraan bernilai positif 0,18 . Angka terse- but memperlihatkan selama periode tahun 2003-2006 kesejahteraan petani meningkat sebesar 18 persen. Yang merasakan hal tersebut lebih dominan kelompok pendapatan terendah. Kelompok berpenghasilan tertinggi (20 persen tertinggi) justru mengalami penurunan kesejahteraan.

Selama periode tahun 2006-2009, berdasarkan survei yang dilakukan tahun 2009 ternyata indek kesejahteraan petani kelapa sawit masih mengalami nilai positif yakni sebesar 0,12 . Walaupun pada tahun 2008-2009 ekonomi dunia mengalami krisis global, namun petani kelapa sawit masih sempat menikmati kesejahteraannya. Hal ini dibuktikan dengan kenaikan kesejahteraan petani sebesar 12 persen.

Rendahnya indek kesejahteraan petani kelapa sawit periode tahun 2006-2009 juga tidak terlepas dari dampak krisis ekonomi global. Hal tersebut menyebabkan harga $\mathrm{CPO}$ di pasaran dunia pada akhir tahun 2008 sampai triwulan pertama tahun 2009 turun. Tentu saja dampak harga ini juga berpengaruh terhadap harga di tingkat petani kelapa sawit. Karena itu indeks kesejahteraan petani kelapa sawit turun dibandingkan periode sebelumnya.

Aktivitas pembangunan perkebunan kelapa sawit memberikan pengaruh eksternal yang bersifat positif atau bermanfaat bagi wilayah sekitarnya. Manfaat kegiatan perkebunan ini terhadap aspek ekonomi pedesaan, antara lain: 1) Memperluas lapangan kerja dan kesempatan berusaha; 2) Peningkatan kesejahteraan masyarakat sekitar; dan 3) Memberikan kontribusi terhadap pembangunan daerah.

Tabel 7. Pertumbuhan Indeks Kesejahteraan Petani Kelapa Sawit Di Daerah Riau

\begin{tabular}{|c|c|c|c|c|c|c|c|c|c|c|}
\hline \multirow{2}{*}{ Kelompok Pendapatan } & \multicolumn{2}{|c|}{ 19951) } & \multicolumn{2}{|c|}{ 19982) } & \multicolumn{2}{|c|}{ 20033) } & \multicolumn{2}{|c|}{ 20064) } & \multicolumn{2}{|c|}{ 20095) } \\
\hline & $\mathbf{w}$ & g & $\mathbf{w}$ & g & $\mathbf{w}$ & g & $\mathbf{w}$ & g & $\mathbf{w}$ & g \\
\hline $20 \%$ pendapatan terendah & 0,0805 & $-0,0084$ & 0,1513 & 0,0708 & 0,1169 & $-0,0344$ & 0,1040 & $-0,0129$ & 0,1127 & $-0,0087$ \\
\hline $20 \%$ pendapatan terendah kedua & 0,1267 & 0,0090 & 0,1946 & 0,0679 & 0,1583 & $-0,0363$ & 0,1590 & 0,0007 & 0,1547 & 0,0043 \\
\hline $20 \%$ pendapatan terendah ketiga & 0,1438 & $-0,0056$ & 0,2152 & 0,0714 & 0,1831 & $-0,0321$ & 0,1791 & $-0,0040$ & 0,1841 & $-0,0050$ \\
\hline $20 \%$ pendapatan terendah keempat & 0,1955 & $-0,0119$ & 0,2010 & 0,0055 & 0,2107 & 0,0097 & 0,2260 & 0,0153 & 0,2197 & 0,0063 \\
\hline $20 \%$ pendapatan tertinggi & 0,4535 & 0,0167 & 0,2379 & $-0,2156$ & 0,3309 & 0,0930 & 0,3319 & 0,0010 & 0,3288 & 0,0031 \\
\hline Indek Pertumbuhan Kesejahteraan & \multicolumn{2}{|c|}{0,49} & \multicolumn{2}{|c|}{$-1,09$} & \multicolumn{2}{|c|}{1,72} & \multicolumn{2}{|c|}{0,18} & \multicolumn{2}{|c|}{0,12} \\
\hline
\end{tabular}

Catatan: Angka 2006 setelah perbaikan

Sumber: 1) Syahza, 1995; 2) Syahza, 1998; 3) Syahza, 2005; 4) Syahza, 2007; 5) Hasil survei, 2009 
Beberapa kegiatan yang secara langsung memberikan dampak terhadap komponen ekonomi pedesaan dan budaya masyarakat sekitar, antara lain: 1) Kegiatan pembangunan sumberdaya masyarakat desa; 2) Pembangunan sarana prasarana yang dapat dimanfaatkan oleh masyarakat setempat, terutama sarana jalan darat; 3) Penyerapan tenaga kerja lokal; 4) Penyuluhan pertanian, kesehatan dan pendidikan; dan 5) Pembayaran kewajiban perusahaan terhadap negara (pajak-pajak dan biaya kompensasi lain).

Kegiatan pengusahaan perkebunan kelapa sawit baik perusahaan inti maupun plasma membutuhkan tenaga kerja langsung (tidak termasuk skilled-labour) dan tenaga teknis perkebunan dalam pengelolaannya. Secara ideal tenaga kerja direkrut dari masyarakat sekitar perkebunan, terutama untuk tenaga kerja teknis perkebunan yang diambil dari masyarakat desa sekitarnya. Kegiatan perkebunan kelapa sawit itu menyerap tenaga kerja cukup banyak, di samping itu kegiatannya bersifat manual se- tenaga kerja lokal adalah: pemanen, timbang dan muat, pembersihan lahan, pemberantasan hama. Dalam analisis ini, upah tenaga kerja untuk panen sekitar Rp65,00 per kg TBS, upah timbang dan muat sekitar Rp20,00 per kg TBS. Pembersihan lahan Rp150.000 per ha per catur wulan, pemupukan dan pemberantasan hama. Dengan asumsi rataan produksi TBS $3.700 \mathrm{~kg}$ per bulan, maka petani akan mengeluarkan upah panen dan timbang sebesar Rp314.500 per petani per bulan. Diasumsikan di tiga kabupaten (daerah penelitian) jumlah petani sebanyak 88.897 KK dengan produksi rataan $3.700 \mathrm{~kg}$ TBS per bulan, maka total upah panen dan timbang yang beredar di masyarakat: Rp27.958.106.500 per bulan. Perputaran uang per catur wulan untuk upah pembersihan lahan di daerah sampel diperkirakan sebesar Rp13.334.550.000. Tingginya jumlah uang beredar di daerah survei akan meningkatkan daya beli masyarakat, secara sinergi akan menimbulkan aktivitas ekonomi di pedesaan dalam bentuk mobilitas barang dan mobilitas penduduk. 
memberikan kontribusi yang besar pada perekonomian negara, maka pemberdayaan ekonomi rakyat juga berarti membangun ekonomi pertanian dengan lebih baik. Lebih lanjut diungkapkan Haryono Suyono (2007), dalam upaya pemberdayaan ekonomi masyarakat pedesaan, sektor pertanian harus menjadi sasaran utama. Sektor ini harus dijadikan pijakan kokoh, sehingga di pedesaan dapat tercapai swasembada berbagai produk pertanian, terutama pangan, sebelum memasuki era pengindustrian. Lebih khusus, ketahanan pangan lokal harus tercapai lebih dahulu dan pertanian harus mendapatkan prioritas utama.

Pengembangan sektor pertanian ke depan harus diarahkan kepada sistem agribisnis, karena pendekatan ini akan dapat meningkatkan nilai tambah sektor pertanian, pada hakekatnya dapat meningkatkan pendapatan bagi pelakupelaku agribisnis di daerah. Menurut Bungaran Saragih (2001b), sektor agribisnis sebagai sektor ekonomi rakyat masih memiliki prospek yang cerah untuk dikembangkan lebih lanjut, baik untuk memperkuat ekonomi rakyat, maupun sebagai andalan Indonesia dalam perdagangan bebas.

Untuk mewujudkan tujuan pengembangan ekonomi kerakyatan, terutama di sektor pertanian maka perlu dipersiapkan kebijakan strategis untuk memperbesar atau mempercepat pertumbuhan sektor pertanian, khususnya peningkatan pendapatan dan kesejahteraan masyarakat. Salah satu cara untuk mencapai tujuan tersebut adalah pengembangan agribisnis yang terencana dengan baik dan terkait dengan pembangunan sektor ekonomi lainnya.

\section{SIMPULAN}

Pembangunan perkebunan kelapa sawit di Daerah Riau telah memberikan dampak terhadap aktivitas ekonomi di daerah pedesaan. Dari segi pendapatan petani berkisar antara Rp3.475.029Rp4.125.242. Jika diasumsikan nilai tukar rupiah terhadap dollar sebesar US $\$ 1=\mathrm{Rp} 9.000$, maka pendapatan petani kelapa sawit berkisar US\$ 4.633,37-US\$ 5.500,32 per tahun. Kegiatan pembangunan perkebunan kelapa sawit telah memberikan dampak terhadap percepatan pembangunan ekonomi masyarakat dalam upaya mengentaskan kemiskinan di daerah pedesaan.

Terdapat perbedaan pendapatan antara petani kelapa sawit plasma dengan swadaya. Perbedaan ini disebabkan, antara lain: 1) distorsi harga antara petani plasma dengan petani swadaya sebesar; 2) kemampuan petani swadaya terhadap pengelolaan kebun masih rendah; 3) pendapatan petani swadaya sangat dipengaruhi oleh harga TBS yang mereka terima karena pasar TBS lebih cenderung monopsonistik; dan 4) keterbatasan pengetahuan petani swadaya terhadap usahatani kelapa sawit.

Kegiatan perkebunan kelapa sawit di pedesaan menciptakan angka multiplier effect sebesar 3,03, terutama dalam lapangan pekerjaan dan peluang berusaha. Tingkat pertumbuhan indeks kesejahteraan petani kelapa sawit di Riau pada tahun 1995 sebesar 0,49 yang berarti tingkat pertumbuhan kesejahteraan meningkat sebesar 49 persen. Tahun 2003 indeks pertumbuhan kesejahteraan petani kelapa sawit meningkat menjadi 1,72. Berarti pertumbuhan kesejahteraan petani kelapa sawit mengalami kemajuan sebesar 172 persen. Pada periode tahun 2003-2006 indeks kesejahteraan petani kelapa sawit 0,18 dan periode tahun 2006-2009 juga mengalami positif sebesar 0,12. Ini berarti kesejahteraan petani pada periode tersebut sebesar 12 persen.

Hasil penelitian yang dilakukan di daerah pedesaan menyimpulkan bahwa pembangunan perkebunan kelapa sawit dapat meningkatkan perekonomian pedesaan. Secara ekonomi akan meciptakan daya beli di daerah pedesaan, yang pada akhirnya meningkatkan permintaan terhadap barang kebutuhan masyarakat.

Perkebunan yang diusahakan secara swadaya sepertinya jalan sendiri tanpa bergantung kepada inti. Untuk pembangunan perkebunan kelapa sawit ke depan perlu dirancang bentuk kelembagaan kelapa sawit di pedesaan yang melibatkan perusahaan, pemerintah daerah dan petani. Konsep ini menekankan kepada asas kepemilikan bersama oleh petani baik usahataninya maupun pabrik pengolahannya, yang pengelolaannya dilakukan oleh koperasi petani.

Bagi masyarakat di daerah pedesaan, sam- 
pai saat ini usaha perkebunan merupakan alternatif untuk merubah perekonomian keluarga, karena itu animo masyarakat terhadap pembangunan perkebunan masih tinggi. Dari sisi lain pembukaan perkebunan akan membutuhkan lahan, apabila hal ini tidak dikendalikan oleh pembuat kebijakan, maka akan terjadi alih fungsi lahan di daerah pedesaan.

\section{DAFTAR PUSTAKA}

Dinas Perkebunan Provinsi Riau. 2009. Laporan Tahunan, Dinas Perkebunan Provinsi Riau, Pekanbaru.

Gumbira-Sa'id, E. dan L. Febriyanti. 2005. Prospek dan Tantangan Agribisnis Indonesia. Economic Review Journal 200. (On-line). http:/ /209.85.135.104/search?q=cache:3EDCELftAoJ:www.bni.co.id/, diakses pada 11 Mei 2010.

Saragih, Bungaran. 2001a. Suara dari Bogor: Membangun Sistem Agribisnis. Bogor: Yayasan USESE.

Saragih, Bungaran. 2001b. Agribisnis: Paradigma Baru Pembangunan Ekonomi Berbasis Pertanian. Bogor: Yayasan USESE.

Sucihatiningsih dan Waridin. 2010. Model Penguatan Kapasitas Kelembagaan Penyuluh Pertanian dalam Meningkatkan Kinerja Usahatani Melalui Transaction Cost: Studi Empiris di Provinsi Jawa Tengah. Jurnal Ekonomi Pembangunan FE UMS Vol. 11, No.1, Juni 2010. Surakarta: BPPE UMS.

Suyono, Haryono. 2007. Gerakan Nasional Pemberdayaan Masyarakat. (On-line). http: // www.hupelita.com/baca.php?id=2751 1, diakses 31 Juli 2009.

Syahza, Almasdi. 2005. Dampak Pembangunan Perkebunan Kelapa Sawit terhadap Multiplier Effect Ekonomi Pedesaan di Daerah Riau, dalam Jurnal Ekonomi, Th. X/03/
November/2005, PPD\&I Fakultas Ekonomi Universitas Tarumanagara, Jakarta.

Syahza, Almasdi. 2002. Potensi Pembangunan Industri Hilir Kelapa Sawit di Daerah Riau, dalam Usahawan Indonesia, No. 04/ TH XXXI April 2002. Jakarta: Lembaga Manajemen FE UI.

Syahza, Almasdi. 2003. Potensi Pembangunan Industri Minyak Goreng di Daerah Riau, dalam Sosiohumaniora, Vol 5 No 1, Maret 2003, Bandung: Lembaga Penelitian Universitas Padjadjaran.

Syahza, Almasdi. 2007. Percepatan Pemberdayaan Ekonomi Masyarakat Pedesaan dengan Model Agroestate Berbasis Kelapa Sawit, dalam Jurnal Ekonomi, Th.XII/02/ Juli/2007, PPD\&I Fakultas Ekonomi Universitas Tarumanegara, Jakarta.

Syahza, Almasdi. 2009. Kelapa Sawit, Dampaknya terhadap Percepatan Pembangunan Ekonomi Pedesaan di Daerah Riau, Penelitian Hibah Kompetensi (tahun Pertama) DP2M Direktorat Jenderal Pendidikan Tinggi Departemen Pendidikan Nasional, Jakarta.

Syahza, Almasdi. 2010. Kelapa Sawit, Dampaknya Terhadap Percepatan Pembangunan Ekonomi Pedesaan di Daerah Riau, Penelitian Hibah Kompetensi (tahun kedua) DP2M Direktorat Jenderal Pendidikan Tinggi Departemen Pendidikan Nasional, Jakarta.

Tambunan, Tulus T.H. 2001. Transformasi Ekonomi di Indonesia Teori dan Penemuan Empiris. Jakarta: Salemba Empat.

Todaro, Michael P. 2006. Pembangunan Ekonomi, Terjemahan oleh Haris Munandar, Edisi kesembilan. Jakarta: Erlangga. 